\title{
海上交通管制業務における管制官の管制過程に関する分析
}

\author{
宋 涁冰 $^{1}$ ・伊藤 博子 ${ }^{2} \cdot 川$ 恭己 $^{3}$ ・福戸 淳司 ${ }^{4}$
}

\section{Analysis of Management Processes of Vessel Traffic Service Operators}

\author{
Binbing SONG, Hiroko ITOH, Yasumi KAWAMURA and Junji FUKUTO
}

\begin{abstract}
Recently, Vessel traffic service (VTS) operators are highly required to get the ability to manage traffic flow, by detecting Conditions that Requires Attention (CRA) from the monitoring screen. The authors elucidated the cognitive processes of VTS operators for detecting CRA, after that they are planning to propose training methods for the inexperienced operators. As the first step of the study, in order to acquire the cognitive contents of VTS operators, we observed the difference of management process between inexperienced and experienced operators by the experimental analysis based on an on-site viewpoint. A series of traffic management process experiments by using a simulator for training VTS operators was carried out for both inexperienced and experienced operators. In order to understand the management process of operators, we proposed a management task chart based on the results of the experiments. The result shows that the inexperienced operator handles a few CRA intensively, while the experienced operators handle many CRA at the same time. It also shows that in order to make more rational the management task, it is necessary to properly select the concerned ship of CRA, the contents and the timing for calling the ship.
\end{abstract}

Keywords : traffic, traffic control, VTS operator, vessel traffic service, simulation management process experiment, management process

キーワード: 交通, 交通管制，運用管制官，運用管制業務，模擬管制処理実験，管制過程

\section{1. 緒論}

現在、業務の効率を向上させるには、様々な業務 支援システムを導入するようになっている。海上交 通管制においても、運用管制官が日々行う運用管制 業務を支援するために、情報処理技術(IT)を活用し たシステムが使われている。しかしながら、業務支 援システムが複雑になるにつれ、それを利用する人 の能力の向上も必要になってきている(1)。

一方、昨年、第 3 次交通ビジョン ${ }^{(2)}$ により、東京
湾における管制一元化 ${ }^{(3)}$ が進められた。これにより、 運用管制官の管制する海域が拡大されるとともに、 管制内容の充実化が求められている。よって、運用 管制官には、より高度な管制能力が求められると共 に、各運用管制官の業務の効率化や管制技能伝承の 迅速化のための技術支援が重要となっている。特に、 著者らは、運用管制官がより早く業務環境に適応す るための、新人向けの新たなトレーニング法の構築 が必要であると考えている。たとえば、新人の育成

\footnotetext{
学生会員 横浜国立大学

2 正会員

3 正会員

4 正会員

\section{海上技術安全研究所 \\ 横浜国立大学 \\ 海上技術安全研究所}

( 干240-8501 横浜市保土ヶ谷区常盤台 79-5 )

( ₹181-0004 東京都三鷹市新川 6-38-1 )

( ₹240-8501 横浜市保土ヶ谷区常盤台 79-5)

( ₹181-0004 東京都三鷹市新川6-38-1 )
}

song-binbing-jb@ynu.jp hiroko@nmri.go.jp kawamura-yasumi-zx@ynu.ac.jp fukuto@nmri.go.jp 
時間を短縮することが可能なトレーニング法が考え られる。

運用管制官の業務のうち、船舶の動静監視業務は、 運用管制官がレーダ処理画面から注意すべき状況を 検出することをきっかけに開始される。検出の早さ、 正確性が危険の早期検知・予防を支えている。従っ て、これらの検出能力を習得するためには、まず運 用管制官が行っている状況の検出作業を十分に理解 することが重要である。

著者らは、運用管制官の注意す心゙き状況の認知プ ロセスを解明し(4)、新人のトレーニング方法を立案 することを考えている。その最初のステップとして、 運用管制官の認知内容を取得する必要がある。本研 究の目的は、船舶の動静監視業務を対象として、現 場の視点に基づいた実験的な分析を行うことによっ て、運用管制官の管制過程について理解することで ある。本稿では、運用管制業務の訓練卓 (以下、訓練 卓という)を用いた模擬管制処理実験の概要を示す とともに、管制作業図を用いた管制過程の分析結果 について報告する。

\section{2. 認知エ学に関する既存研究}

Hollnagel,E.は、人間行動は、それが行われる状況 によって主に決定され、その本質は状況の全体性の 中にあると主張している( ${ }^{(5)}$ 。このような認知作用を モデル化したものとして、状況決定制御モデル (COCOM:Contextual Control Model) ${ }^{(5)}$ と意思決定モデ ル(RPD:Recognition Primed Decision model) ${ }^{(6)}$ (以下、 RPD と記す)が挙げられる。

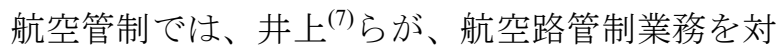
象に、実験的なアプローチによって、管制官のタス ク分析を行った。そして、RPDに基づき、意思決定 プロセスについてのヒューマンモデルを構築した。 また、青山ら ${ }^{(8)}$ が、RPD に基づき、航空管制パフォ ーマンスの評価指標を確立した。

一方、海上交通管制では、認知工学的な観点から 管制作業を分析し、運用管制官の業務支援対策を提 案するような研究は行われていない。よって、本研 究では、模擬管制処理実験を実施することにより、 運用管制官の管制過程と認知プロセスについて分析 する。

\section{3. 船舶の動静監視業務の概要}

運用管制業務は IALA(International Association of Marine Aids to Navigation and Lighthouse
Authorities:国際航路標識協会)の VTS(Vessel Traffic Services)マニュアルに記載されたVTS 業務のことで ある。日本における VTS 業務は、大きく情報提供業 務、勧告・指示等業務、及び航行管制業務から構成 されている(9)。これらは、船舶の動静を情報収集及 び監視により把握する動静監視業務に基づき実施さ れる。

東京湾海上交通センターが行う船舶の動静監視 業務の対象海域は東京湾内と湾外である。東京湾内 は、レーダー、AIS(Automatic Identification System: 船舶自動識別装置)、テレビカメラで船舶の動静を把 握する。湾外は、AIS のみで把握する。把握した船 舶に対して必要な情報を国際 VHF 無線電話、船舶電 話等により提供する(9)。

運用管制官はこの海域において主にレーダ処理 画面を通じ、管制海域における船舶の動静等を確認 し、注意すべき状況を発見する。そして、関係船舶 に対して情報提供、警告、勧告といった運用管制業 務によって、海上交通の安全性や効率性を維持して いる。なお、船舶に対して勧告や指示を行う場合、 海域全体を統括する統括運用管制官が最終判断を行 う(10)。

上記の業務内容を更に作業動作に分けると、以下 のようになる。まず運用管制官はレーダ処理画面に 表示されている船舶を見たり、クリックしたりする ことによって、船舶動静の変化を監視し情報の収集 業務を行う。次に注意すべき船舶を呼び出し、その 情報を伝える。運用管制官が船舶の動静变化を監視 している最中に、船舶から呼び出され、助言等を求 められることもある。

\section{4. 訓練卓を用いた模擬管制処理実験}

\section{1 実験概要}

本研究では、実際に海上保安庁所有の訓練卓を用 い事前にシナリオ(レーダ処理画面に表示される海 上交通状況）を一つ用意して、模擬管制処理実験を行 い、主に運用管制官の業務内容について観察した。 2017 年 11 月 6 日に旧東京湾海上交通センター(観音 崎)にて模擬管制実験を行った。図 1 に実験の様子を 示す。

実験の目的は、運用管制業務を行う際の運用管制 官の作業動作、及び運用管制官が扱う情報を記録す ることである。そして、記録された動作・情報を用 いて、以後の管制作業図を作成・解析寸る。 


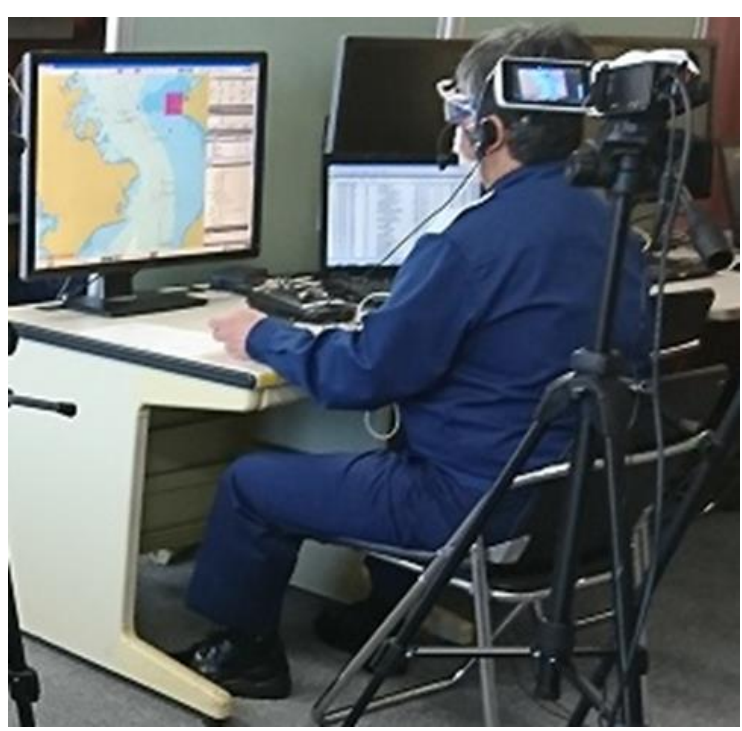

図 1 模擬管制処理実験の様子

\section{2 実験シナリオ}

実験シナリオは、東京湾内に入るため、大型コン テナ船及び危険物船などが多く通る浦賀水道航路と 中ノ瀬航路を中心とする海域を対象として作成した。 図 2 に対象海域を示寸。シナリオの時間帯について は、朝の時間帯が一番交通量が多いため、7 時から 8 時までの間の 20 分間とし、注意すべき状況を組み込 んだ。

これらの状況を本研究では、イベントと呼ぶ。実験 シナリオ作成の際には、協力者のベテラン管制官と、 3 つのイベントを設定した。これらのイベント(イ心゙ ント 1～3）は、交通流をべースに、一部の船舶の動 きを操作して、発生させた。また、以上の 3 つのイ ベントの他に、実験中、被験者が発見したイベント が 6 つ存在した。よって、本シナリオには合計 $9 つ$ のイベントが含まれる。

例としてイベント 1 の内容を説明する。イベント 1 は浦賀水道航路の屈曲部付近で観察されるもので、 北航船が追い越しの際に航路外に出てしまう状況で ある。このような場合、追い越す船舶が追い越され る船舶一与える影響や、航路外から航路内一戻る際 の航路内の船舶一の影響に注意するとともに、この 状況を発見した場合には、関係船舶一の注意喚起が 必要である。他に、追い越す船舶が航路外に出た後、 浅瀬に乗り上げる恐れがある場合には、追い越す船 舶への注意酮起も行われる。このように、運用管制 官が実験中にイベントを認識した際には、必要な対

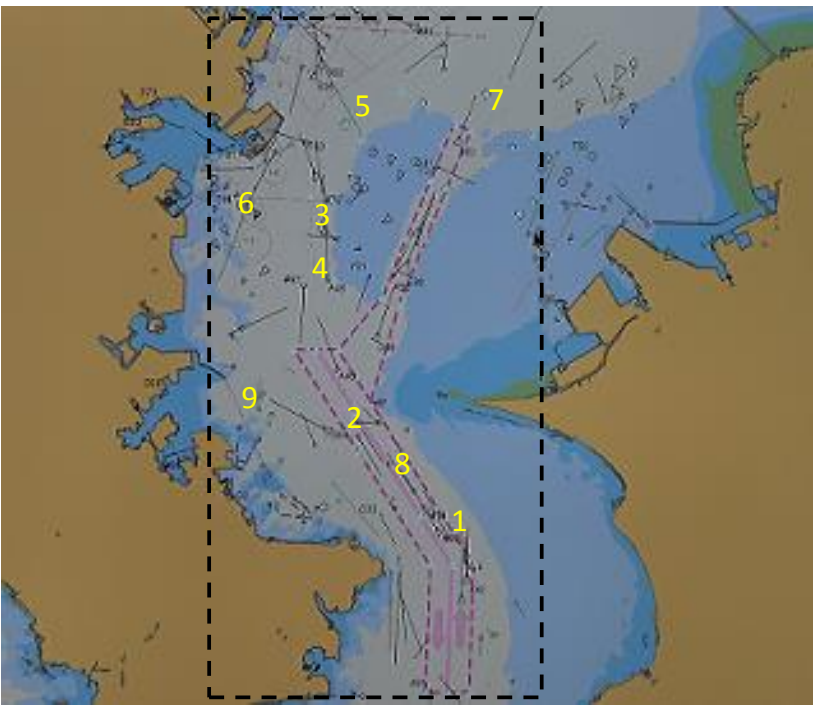

図 2 本実験における対象海域 (イベント 1〜9の発生位置表示)

応が求められる。

なお、本実験を実施する前には、被験者の運用管 制官に、シナリオにイベントが含まれる等の情報は 伝えず、普段通りに管制業務を行うように依頼した。

また、本実験では、すべての被験者に対して同一 のシナリオを設定しているが、完全に同一の条件と することは難しく、イベント 2 における関係船舶か らの動静報告時刻にずれが生じている。しかしなが ら、本実験のように多くのイベントが含まれる同一 のシナリオで実験を行うことにより、被験者間の違 いの観察が可能になると考えている。

\section{3 実験システム}

図 3 に実験システムの構成(赤い線 : 記録・表示 装置間のケーブル、青い線 : 電源コード)を示す。実 験記録のためのシステムについて、運用管制官の作 業動作及び運用管制官が扱う情報をできる限り記録 寸るために、ビデオカメラを 3 台用い、管制業務全 体を観察するとともに、レーダ処理画面と入航予定 船舶リス卜画面上において行った操作、無線通信の 内容、運用管制官間の会話の内容を、映像と音声で 記録した。また、レーダ処理画面上での操作時に、 画面上で注視している内容を把握するために、視線 を追跡する装置 (グラス型アイトラッカー ${ }^{(11)}$ )を使っ て、視線の動きのデータを取得し、記録した。 


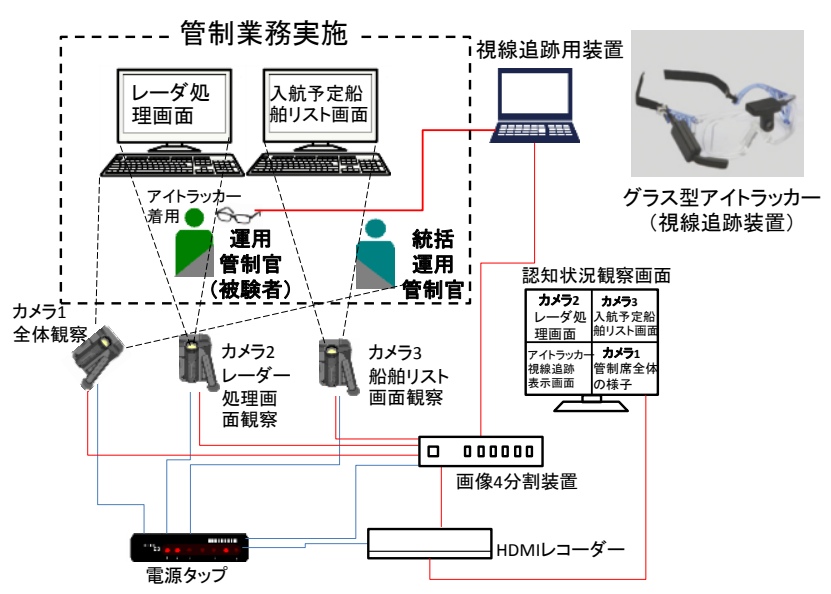

図 3 実験システムの構成

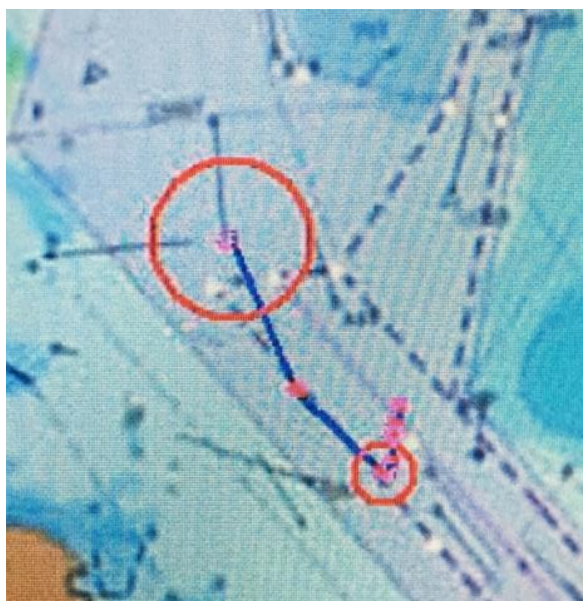

図 4 アイトラッカー画面における視線表示図

図 4 にアイトラッカーにより追跡された視線位置 の表示の例を示す。視線の動きは、注視点(ピンク点) から次の注視点まで折れ線 (青い線)によって繫げて 表示される。

また、注視点の丸 (赤い丸)の大きさは、注視時間 の長さを示している。本実験においては、注視点が 各イベントの発生海域に留まったときは、該当イベ ントを「見る」動作を行っているものとみなした。

\section{4 実験方法}

本実験は、3 名の運用管制官を被験者として、順 番に実施した。実験直前に、協力者のベテラン管制 官が、管制対象海域範囲の説明を行った後、約 3 分 間、被験者に視線追跡用グラスを着用してもらうな どのアイトラッカーのセッティング作業をした。ま た、実験終了後に約 15 分間、それぞれの被験者にイ ンタビューを行い、情報提供などの運用管制業務の 意図について質問した。

表 1 に 3 名の被験者についての情報を示す。これ
表 1 被験者データ

\begin{tabular}{|c|c|c|}
\hline & レベル & 管制官歴 \\
\hline 被験者1 & 新人 & 8ヶ月 \\
\hline 被験者2 & 中堅 & 4年8ヶ月 \\
\hline 被験者3 & ベテラン & 5年8ヶ月 \\
\hline
\end{tabular}

らの被験者のレベルは、管制官経歴年数によって、2 年未満の者は新人レベル、2 年以上 5 年未満の者は 中堅レベル、5 年以上の者はベテランレベルという 目安にするとともに、最終的に、運用管制官の教育 情報や経験を考慮して決定した。

\section{5. 解析結果}

実験データに基づき、イベント毎に管制過程を把 握する。観察されたすべての作業動作を抽出し、イ ベント毎に整理した。時系列で見たイベント毎の管 制作業を図 5 のようにまとめた。被験者が関係船舶 に注意喚起をしたイベント、すなわち、実際に検出 したイベントの管制過程のみを解析対象にした。こ れを管制作業図と呼ぶ。本研究では、この管制作業 図を用いて、新人と中堅・ベテランにおける管制過 程の違いを解析した。具体的には、運用管制業務中 に観察された作業動作全体、及び個別の動作を解析 した。

\section{1 時系列で見たイベント毎の管制作業}

管制作業図(図 5)においては、縦軸はイベント、横 軸は時間を表す。時間はシナリオ内の設定時刻を表 している。図のように、運用管制業務はいくつかの 作業動作によって構成されている。本研究では、「呼 び出され」、「見る」、「クリック」、「呼び出し」とい った 4 つ作業動作に着目した。「呼び出され」とは、 船舶から海上交通センターに船舶情報の連絡が入る ことである。「見る」とは、運用管制官がレーダ処理 画面から船舶の動静を見ることである。「クリック」 とは、運用管制官がレーダ処理画面上において船舶 情報を確認するために、船舶をクリックすることで ある。「呼び出し」とは、運用管制官が注意すべき であると判断した船舶を呼び出すことである。

本研究では、イベントの中心的な船舶を理解しや すくするため、「本船」と「周辺船」の概念を導入し た。「本船」とは、イベントに潜んでいる危険を起こ しそうな船舶、あるいは異常な動きを取っている船 舶のことである。「周辺船」は、本船の周辺にいて、 本船の影響を受けそうな船舶のことである。通常の 

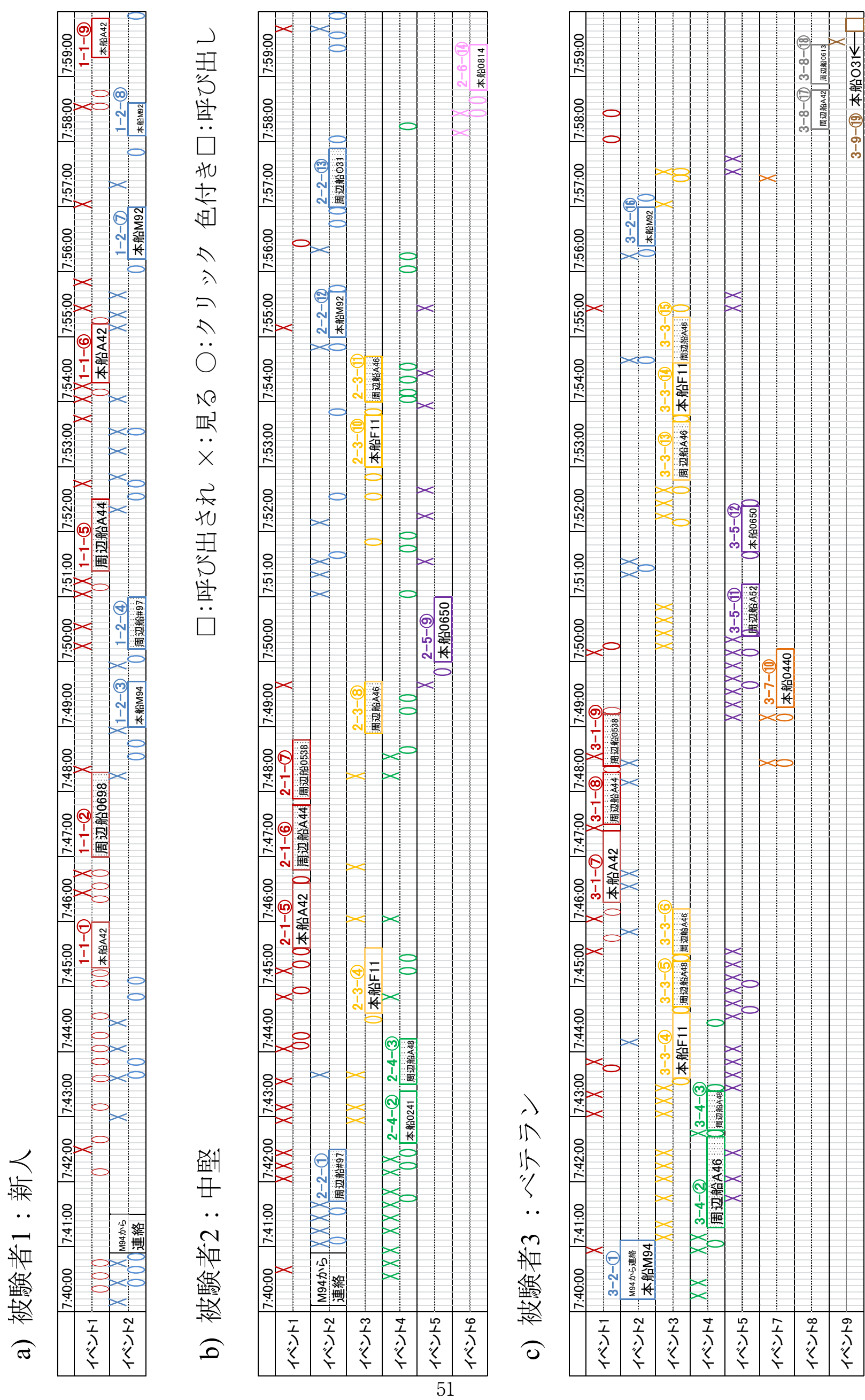

疽
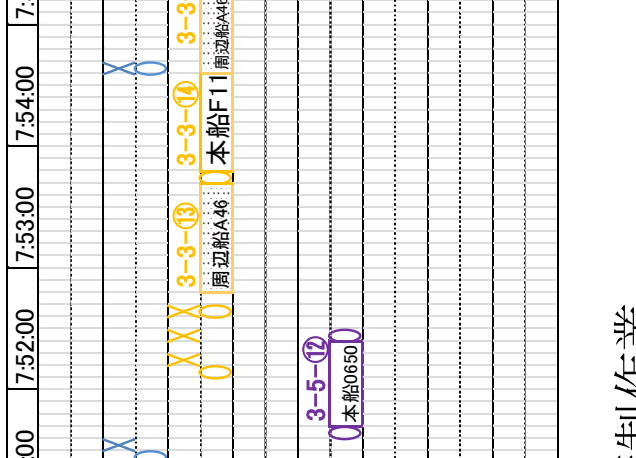

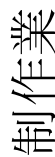
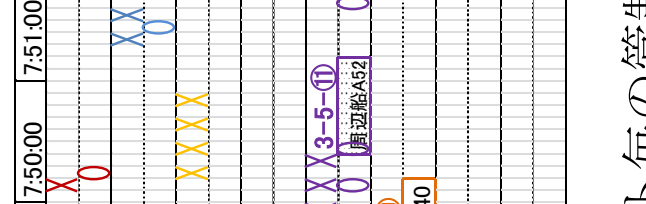

进

:

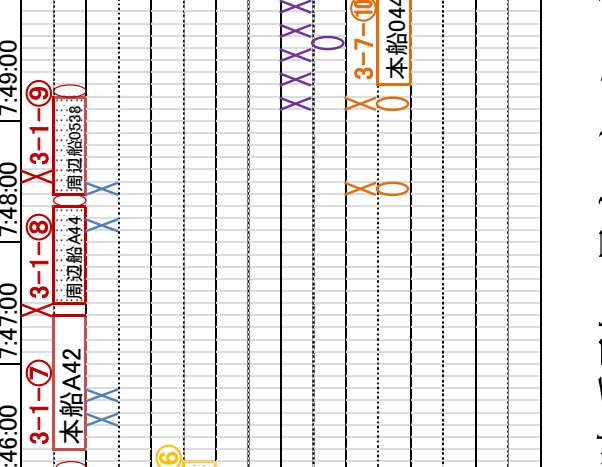

分

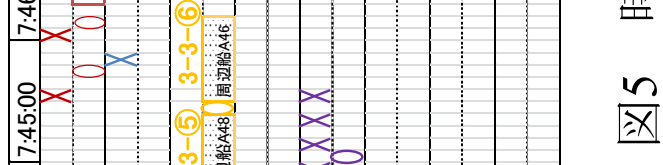

I

IN

"L 年

.

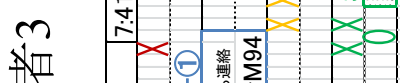

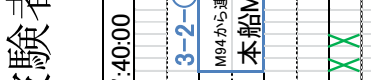

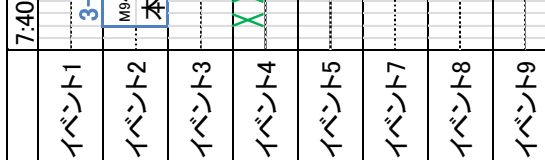

in 
場合は、本船と周辺船が衝突する可能性があると考 えられる。

図の中に示された×(バツ)と $\mathrm{O}$ (楕円)については、 それぞれ「見る」と「クリック」を表している。船 舶からの「呼び出され」は長方形内に「船舶 ID 名 から連絡」で記す。イベントに関係する船舶に対す る「呼び出し」は長方形内に「本船＋ID 名」または 「周辺船 $+\mathrm{ID}$ 名」で記した。また、イベントに対す る呼び出し毎に番号を「被験者番号-イベント番号呼び出し順番号」で付けた。

\section{6. 考察}

図 5 から、管制過程が以下のように観察された。 被験者は主に「見る」「クリック」をすることを通じ、 船舶の動静変化に関する情報を収集し、注意すべき 状況を判断する。そして、「呼び出し」といった行動 を取っている。すなわち、認知の観点から何らかの 情報を認識し、注意す心゙き状況であるかどうか判断 した上で、何らかの行動を決定・実行したと考えら れる。よって、主に認識すべき情報内容、及び決定 す心゙き行動内容を切口として、被験者による管制過 程の共通点と相違点を以下にまとめる。

なお、上記に示す一つの管制過程を一サイクルと 呼ぶ。

また、管制過程における「呼び出し」について、 セットと回という単位を設定して、説明する。一セ ットの呼び出しは、一回、または複数回の呼び出し によって構成されている。例えば、図 5 の a)より、 被験者 1 はイベント 1 に対して 1 回目の呼び出しを 行い、そのイベントの動静を確認したのちに、すぐ 2 回目の呼び出しを行った。b)より、被験者 2 はイ ベント 1 に対して 1 回目、2 回目、3 回目の呼び出し を次々と行った。このような複数回の呼び出しのこ とを一セットの呼び出しと呼ぶ。

\section{1 管制過程の一サイクルにおける船舶を呼 び出す際の確認方法}

(1) 図 6 に、被験者 2 と 3(中堅とベテラン)のイベン 卜 4 に対する 1 セット目の呼び出し状況をまとめた。 イベント 4 は、A46、A48 及び 0241 といった 3 隻の 船舶によって構成される(図 5)。図 6 では、それぞ れ $\mathrm{A} 、 \mathrm{~B} 、 \mathrm{C}$ 船で記す。図 6 から、被験者ごとに呼 び出した船舶が違うが、両者とも呼び出さなかった 船舶の「クリック」は行ったため、事前に該当イベ ントの関係船舶をすべて確認した上で、対象船舶を 呼び出した点は共通していることがわかる。

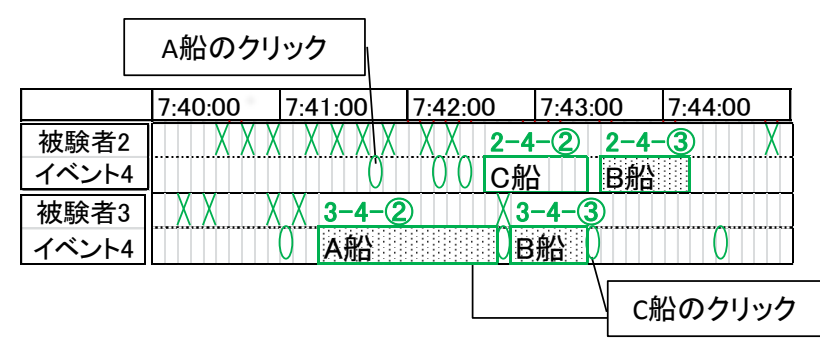

図 6 被験者 2 と 3 のイベント 4 に対する 1 セット 目の呼び出し

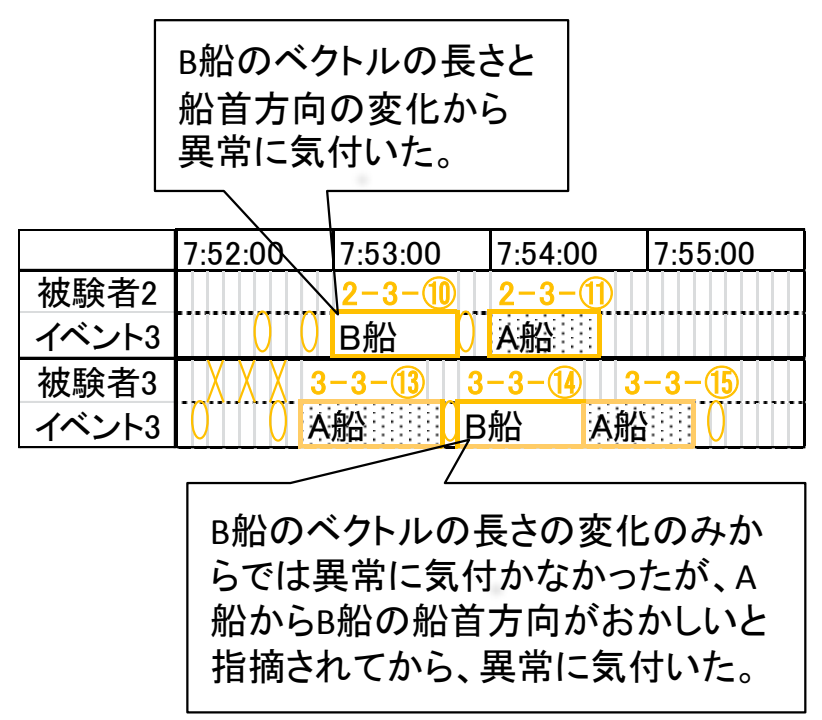

図 7 被験者 2 と 3 のイベント 3 に対する 2 セット 目の呼び出し及びインタビューの回答内容

(2) 図 7 に、被験者 2 と 3(中堅とベテラン)のイベン 卜 3 に対する 2 セット目の呼び出し状況及びインタ ビューの回答内容をまとめた。

イベント 3 は、A46、A48 及び F 11 (異常船舶) とい った 3 隻の船舶によって構成される(図 5)。被験者 2 と 3 のイベント 3 に対する 2 セット目の呼び出し付 近では、A46、F11 船のみが呼び出された。図 7 では、 それぞれ A、B 船で記す。イベント 3 では、被験者 ごとに最初に呼び出した船舶が違い、インタビュー 回答を確認した所、異常船舶の B 船に気づくまでの 過程が被験者によって異なっていた。中堅が船舶の ベクトルの長さも船首方向も確認したため、ベテラ ンより早く異常船舶に気づいたことがわかる。

\section{2 同時に管制処理したイベント数}

図 5 より被験者のレベルにより呼び出すイベント 数に関して以下の傾向が観察できる。 
表 2 同じ時間帯に並行して「見る」「クリック」 及び「呼び出し」を行ったイベント数

\begin{tabular}{|c|c|c|c|c|c|c|}
\hline 開始時間 & $7: 40: 00$ & $7: 44: 00$ & $7: 48: 00$ & $7: 52: 00$ & $7: 56: 00$ & 平均 \\
\hline 終了時間 & $7: 44: 00$ & $7: 48: 00$ & $7: 52: 00$ & $7: 56: 00$ & $8: 00: 00$ & (個) \\
\hline 被験者1 & 2 & 2 & 2 & 2 & 2 & 2 \\
\hline 被験者2 & 4 & 3 & 5 & 5 & 4 & 4 \\
\hline 被験者3 & 5 & 5 & 5 & 4 & 7 & 5 \\
\hline
\end{tabular}

(1) 図 5 に示すように、各被験者の呼び出したイ心゙ ント数から、被験者のレベルが上がれば、呼び出す ことが可能なイベント数が多くなる。

(2) 表 2 に同じ時間帯に並行して各被験者が「見る」 「クリック」及び「呼び出し」を行ったイベント数 をまとめた。20 分間の実験シナリオを均一に幾つか の時間枠に区切り、その中で、4 分間が一番各被験 者の違いを観察するのに有効であると判断した。そ こで、4 分間毎に各被験者が処理したイベント数を 収集し、平均值を出した。表 2 から、被験者のレベ ルが上がれば、同じ時間帯に並行して、イベントを より多く処理している傾向がある。

また、いずれの被験者も同じ時間帯に複数のイ心゙ ントを処理していることから、一つのイベントに関 係する船舶を呼び出していると同時に、他のイベン 卜の船舶動静にも注意を払っている。

\section{3 一つのイベントに対する管制処理サイク ル}

いずれの被験者も 1 セット目の呼び出しの後、そ のイベントの関係船舶の動静変化に注意を払い、必 要に応じて 2 回目以降の呼び出しを行うことがわか った。例えば図 5 の c)より、被験者 3 はイベント 3 に対して、最初に呼び出しを行った後、3つのイべ ントにそれぞれ関係する船舶を順に呼び出したのち に、イベント 3 を確認してから、すぐに 2 セット目 の呼び出しを行った。

つまり、一つのイベントに対して、「呼び出し」 までの管制過程が一サイクルだけではなく、何サイ クルも該当イベントを見て、クリックして、情報収 集していることが共通している。

一方、図 5 に示すように、イベント 1 に対して、 新人は 4 セット呼び出しを行ったが、中堅・ベテラ ンは 1 セットだけ呼び出しを行った。それに、イベ ント 2 に対して、新人は「呼び出され」の後、暫く 関係船舶の動静を確認してから、1 セット目の呼び 出しを行ったが、中堅・ベテランは「呼び出され」 の後すぐ、 1 セット目の呼び出しを行った。これら のことから、新人のトレーニング法を改善する際に、
表 3 被験者 3 名のイベント 1 に対する各「呼び出 し」の方法

\begin{tabular}{|c|c|c|c|c|c|c|c|c|c|c|c|}
\hline & & \multirow{2}{*}{\multicolumn{2}{|c|}{$\begin{array}{c}\text { No.1 } \\
\text { 呼7\&出 }\end{array}$}} & \multirow{2}{*}{\multicolumn{2}{|c|}{ 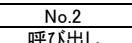 }} & \multicolumn{2}{|c|}{ No.3 } & \multicolumn{2}{|c|}{ No.4 } & \multicolumn{2}{|c|}{ No.5 } \\
\hline & & & & & & & び出し & 呼? & א出し & 呼已 & 出し \\
\hline & レベル & 船舶 & 内容 & 船舶 & 内容 & 船舶 & 内容 & 船舶 & 内容 & 船舶 & 内容 \\
\hline 被験者1 & 新人 & 本船 & 勧告 & $\begin{array}{l}\text { 周辺 } \\
\text { 船 } \mathrm{B}\end{array}$ & $\begin{array}{l}\text { 情報提供 } \\
\text { (本船) }\end{array}$ & $\begin{array}{l}\text { 周辺 } \\
\text { 船 } \mathrm{A}\end{array}$ & $\begin{array}{c}\text { 情報提供 } \\
\text { (本船) }\end{array}$ & 本船 & $\begin{array}{l}\text { 情報 } \\
\text { 確認 }\end{array}$ & 本船 & $\begin{array}{l}\text { 情報 } \\
\text { 確認 }\end{array}$ \\
\hline 被験者2 & 中堅 & 本船 & $\begin{array}{c}\text { 勧告· } \\
\text { 情報確認 } \\
\end{array}$ & $\begin{array}{l}\text { 周辺 } \\
\text { 船A }\end{array}$ & $\begin{array}{l}\text { 情報提供 } \\
\text { (本船) }\end{array}$ & $\begin{array}{l}\text { 周辺 } \\
\text { 船C }\end{array}$ & $\begin{array}{l}\text { 情報提供 } \\
\text { (本船) }\end{array}$ & & & & \\
\hline 被験者3 & ベテラン & 本船 & 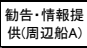 & $\begin{array}{l}\text { 周辺 } \\
\text { 船A }\end{array}$ & $\begin{array}{l}\text { 情報提供 } \\
\text { (本船) }\end{array}$ & \begin{tabular}{l|} 
周辺 \\
船
\end{tabular} & $\begin{array}{l}\text { 情報提供 } \\
\text { (本船) }\end{array}$ & & & & \\
\hline
\end{tabular}

呼び出しのセット数とタイミングを適切に決める必 要があると考えられる。

\section{4 一つイベントに対する各「呼び出し」 の方法}

前節では、セット単位の呼び出しについて、説明 したが、ここでは、回ごとの呼び出しについて、説 明する。

一回の「呼び出し」は、呼び出し船舶、呼び出し

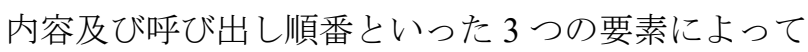
構成される。表 3 に被験者 3 名のイベント 1 に対寸 る各「呼び出し」の方法をまとめた。イベント 1 は、

A42、A44、0698 及び 0538 といった 4 隻の船舶によ って構成される(図 5)。表 3 では、それぞれ本船、 周辺船 $\mathrm{A}$ 、周辺船 $\mathrm{B}$ 、周辺船 $\mathrm{C}$ で記す。上記の 3 つ の要素から、新人と中堅・ベテラン間を比較したと ころ、以下の共通点と相違点が確認できる。

(1) 呼び出し船舶から、3 名ともNo.1の呼び出しで 本船に勧告を出した点が共通している。そして、3 名とも各呼び出しでは本船と周辺船 $\mathrm{A}$ に着目してい た。一方、注目したもう一隻の周辺船が被験者によ って異なっていた。新人はN No.2 の呼び出しで周辺船 B に注目したが、中堅・ベテランはNo.3 の呼び出し で周辺船 C に注目した。

上記のことから、新人のトレーニング法改善のた めに、イベントを構成したすべての関係船舶から、 呼び出す必要がある船舶のみを正しく選定する必要 があると考えられる。

(2) 呼び出し内容から、3 名とも本船(周辺船)を呼び 出してから、本船(周辺船)に周辺船(本船)の情報を提 供していた点が共通していることから、3 名ともイ ベントの関係船舶については、本船と周辺船に分け るといった概念を持っていることが分かる。

一方、本船の呼び出し内容については、被験者に よって異なっていた。No.1の呼び出しは、新人は本 船に勧告のみを出したが、中堅・ベテランは勧告以 外に、本船の情報確認、周辺船の情報提供なども加 
えた。そのため、呼び出し数も被験者によって異な っていた。すなわち、新人はNo.4 と No.5 の呼び出 しを行い、本船の情報確認をしていたが、中堅・ベ テランは No.4 以後の呼び出しをする必要がなかっ た。このことから呼び出しの際に関係船舶に確認・ 提供する内容を適切に選定することにより、より合 理的な管制が可能になると考えられる。

(3) 呼び出しの順番については、3 名ともNo.1 の呼 び出しで本船を、No.2 と No.3 の呼び出しで周辺船 を対象船舶にしていたことが共通していた。一方、 周辺船 $\mathrm{A}$ について、呼び出し順番が被験者によって 異なっていた。新人は No.3 に周辺船 A を呼び出し たが、中堅・ベテランは No.2 に周辺船 A を呼び出 した。

上記のことから関係船舶に呼び出すタイミングを 適切に予測する、つまり、新人のトレーニング法を 改善する際に、各船舶の呼び出し順番を適切に決め る必要があると考えられる。

\section{7. 結論}

本研究では、訓練卓を用いて新人と中堅・ベテラ ンの運用管制官を被験者とした模擬管制処理実験を 実施した。管制過程を分析するために、アイトラッ カーを用いて視線の動きデータを計測するとともに、 ビデオにより音声や映像を記録した。実験結果から、 管制作業図を作成した。管制作業図を分析すること によって、新人と中堅・ベテラン間における管制過 程の違い、及び運用管制業務をするにあたっての認 知内容について考察した。

（1）新人と中堅・ベテランの管制過程を比較するこ とにより、新人は、少数の注意すべき状況をより集 中的に処理している一方、中堅・ベテランは、多数 の注意すべき状況を同時に処理していることが観察 された。

(2) 各被験者の呼び出しまでの状況を観察すること により、注意すべき状況の認知プロセスは以下のよ うになると考えられる。まず、該当イベントを構成 するす心゙ての関係船舶を見極める。次に、本船と周 辺船の概念の下で、関係船舶における位置関係を確 認した上で、呼び出しに必要な船舶及び呼び出し内 容を正しく選定する。最後に、呼び出しのタイミン グを適切に決定する。

以上のように本研究では、中堅・ベテランと新人 の認知方法や注意すべき状況の処理方法の違いにつ いて理解することができた。今後、これらの観察結
果に基づいて、運用管制官の認知プロセスを解明・ 分析するとともに、新人の育成時間短縮につながる トレーニング方法の提案を行いたいと考えている。

\section{謝辞}

本研究プロジェクトのためにご協力いただいた 第三管区海上保安本部交通部並びに東京湾海上交通 センターの皆様に厚く御礼申し上げます。

\section{参考文献}

(1) 古田一雄-長崎晋也: 安全学入門, 第 1 章, pp.9-11,2007.

(2) 海上保安庁:〈第 3 次交通ビジョン〉, http://www.kaiho.mlit.go.jp/info/kouhou/h25/k2013 1003/k131003-3.pdf,2019.1.

(3) 第三管区海上保安本部：一元化リーフレット (PDF), http://www.kaiho.mlit.go.jp/03kanku/ichigenka/pdf/ ichigenka_j.pdf,2019.1.

(4) Binbing SONG,Hiroko ITOH,Yasumi KAWAMURA and Junji FUKUTO:Analysis of Cognitive Processes of Operators of Vessel Traffic Service, the $16^{\text {th }}$ World Congress of the International Association of Institutes of Navigation(IAIN),D8-1,2018.11.

(5) Hollnagel,E. : 認知システム工学一情況が制御を 決定する一,第 4 章, pp.167-194,1996.

(6) G.Klein:Source of Power,Chapter 3,pp.23-30,1998.

(7) 井上諭 : 航空路管制業務における管制官のヒュ ーマンモデルに関する研究, 東京大学大学院博 士論文, 2006.

（8）青山久枝・塩見格一・飯田裕康: 管制パフォー マンスの評価指標の確立,「航空管制のヒューマ ンファクタ」シンポジウム, 東京大学, 2008.

（9）東京湾海上交通センター：東京湾海上交通セン ターリーフレット(PDF),

https://www6.kaiho.mlit.go.jp/tokyowan/topics/leafl et.pdf,2019.1.

(10) 日本海難防止協会:[特集]東京湾海上交通管制の 一元化運用開始(PDF), 海と安全 No.575, http://www.nikkaibo.or.jp/pdf/575_2017.pdf,2019,1.

(11) 竹井機器工業株式会社：トークアイライトカタ ログ, http://www.takei-si.co.jp/pdf/TalkEye\%20Lite.pdf,2 019.1 . 